\title{
HEMIHIPERTROFIA IZOLATĂ LA SUGAR
}

\author{
Lorena Elena Meliț ${ }^{1}$, Cristina Oana Mărginean' ${ }^{1}$ Claudia Bănescu ${ }^{2}$, \\ Raluca Damian ${ }^{3}$, Andreea Dincă ${ }^{1}$, Claudiu Mărginean ${ }^{4}$ \\ ${ }^{1}$ Clinica Pediatrie 1, Universitatea de Medicină şi Farmacie, Târgu Mureş \\ ${ }^{2}$ Departamentul de Genetică Medicală, \\ Universitatea de Medicină şi Farmacie, Târgu Mureş \\ ${ }^{3}$ Clinica de Neonatologie 1, Universitatea de Medicină şi Farmacie, Târgu Mureş \\ ${ }^{4}$ Clinica de Obstetrică şi Ginecologie 1, \\ Universitatea de Medicină şi Farmacie, Târgu Mureş
}

\begin{abstract}
REZUMAT
Hemihipertrofia sau hemihiperplazia este o boală congenitală rară, a cărei incidenț̆ este dificil de estimat din cauza faptului că asimetria este foarte uşoară în multe cazuri, rămânând astfel nediagnosticate. Hemihiperplazia poate fi izolată sau asociată unor sindroame genetice. Prezentăm cazul unui sugar, de sex feminin, în vârstă de 6 luni, la care în perioada perinatală s-a ridicat suspiciunea unei hemihipertrofii congenitale, internându-se în clinica noastră din cauza prezentei unei asimetrii faciale. Examenul obiectiv a scos în evidență, de asemenea, pe lângă hemihiperplasia hemifeței drept, mai evidentă la nivelul frunții, o hipertrofie a membrului superior şi inferior drepte. Analizele de laborator au identificat o uşoară anemie, nivele crescute ale transaminazelor, precum şi al alfa-fetoproteinei. Ecografia abdominală a decelat uşoară hepatomegalie, iar cea transfontanelară discretă ventriculomegalie şi atrofie frontală. Testul genetic a fost negativ, astfel că diagnosticul final a fost de hemihipertrofie izolată. Reevaluările ulterioare au arătat un nivel al alfa-fetoproteinei în scăderea, fără alte elemente patologice adiționale. Particularitatea cazului constă în diagnosticarea unei hemihipertrofii izolate la un sugar de 6 luni, cu test genetic negativ, la care s-a observat o uşoară asimetrie facială în momentul naşterii, cu evoluție ulterioară favorabilă, cu scădere progresivă a nivelului alfa-proteinei şi ecografie abdominală normală.
\end{abstract}

Cuvinte cheie: hemihipertrofie izolată, hemihiperplazie izolată, sugar, alfa-fetoproteina

\section{INTRODUCERE}

Hemihipertrofia reprezintă o patologie genetică rară, caracterizată prin creşterea excesivă a unei jumătăți a corpului în totalitate sau doar a unei zone din corp, cum ar fi fața, abdomenul sau unul dintre membre (1-3). Această creştere excesivă poate fi datorată atât unei hiperplazii a țesuturilor moi, cât şi a țesutului osos, sau a ambelor (4), ducând la o asimetrie corporală care poate fi observată în momentul inspecției ca parte a oricărui examen obiectiv efectuat de rutină, atât de către medicul pediatru, cât şi de către medicul de familie. Hemihipertrofia sau mai nou numită hemihiperplazia poate fi izolată sau poate fi parte a unor sindroame genetice, precum: Beckwith-Wiedemann, Proteus, Russel-Silver, neurofibromatoza de tip 1 sau sindromul Klippel-Trénaunay-Weber $(2,3)$. În momentul suspicionării unei hemihipertrofii, medicul pediatru are obligația de a solicita un consult gene- tic în vederea excluderii unuia dintre sindroamele menționate mai înainte. Fiecare dintre aceste sindroame prezintă asociat hemihiperplaziei, alte trăsături bine definite, care împreună vor duce la un prognostic diferit pentru fiecare sindrom genetic. Astfel că rata mortalitătii, precum şi protocoalele de monitorizare sunt diferite pentru fiecare din aceste patologii (5). Testul genetic cu analiza cariotipului este cel care va diferenția aceste sindroame de hemihiperplazia izolată.

Hemihiperplazia izolată este de cele mai multe ori subdiagnosticată din cauza faptului că multe dintre cazuri sunt forme uşoare în care hemihipertrofia este foarte dificil de identificat, astfel că vor trece neobservate. Prin urmare, incidența acestei patologii este foarte greu de estimat în populația generală. $\mathrm{Cu}$ toate acestea, prevalența estimată a hemihipertrofiei izolate este de aproximativ 1 la 13.200 de nou-născuți vii (6). 
Hemihiperplazia izolată, mai ales la nivelul unui membru, superior sau inferior, trebuie întotdeauna diferențiată de hemiatrofie, care este caracterizată de o scădere în dimensiune şi volum a unor celule care aparțin unui anumit țesut, ca o consecință a unor diverse condiții, precum: ischemia, modificările hormonale sau malnutriţia (7). Pacienții diagnosticați cu hemihipertrofie prezintă un risc crescut de a dezvolta tumori pe parcursul vieții, predominant embrionare (4). Astfel, ghidurile de management al unui caz de hemihipertrofie recomandă următoarele: orice copil suspectat cu hemihipertrofie izolată trebuie îndrumat către consult genetic, efectuarea unei ecografii abdominale la fiecare 3 luni până la vârsta de 7 ani, dozarea alfa-fetoproteinei o dată la 3 luni până la vârsta de 4 ani, precum şi învățarea aparținătorului/părinților de a palpa abdomenul copilului zilnic sau cât mai des posibil.

\section{PREZENTARE DE CAZ}

Prezentăm cazul unui sugar, de sex feminin, în vârstă de 6 luni, care a fost internată în clinica noastră din cauza prezenței unei asimetrii faciale. Antecedentele heredo-colaterale nu au evidentiat elemente patologice semnificative. Antecedentele personale au subliniat faptul că pacienta provine din a doua sarcină, afirmativ fiziologică, monitorizată, este născută la termen, fără complicații ante- sau perinatale, având greutatea la naştere $3.400 \mathrm{~g}$ şi scor APGAR necunoscut, după naştere observându-se o uşoară asimetrie facială, care inițial a fost interpretată în contextul travaliului, însă cu toate acestea a fost recomandat consult pediatric ulterior. Aparținătorii au omis această recomandare, astfel că în contextul unei intercurente respiratorii, medicul de familie a observat la examenul clinic persistența acestei asimetrii faciale, asociate cu hipertrofia membrului superior şi inferior drept, îndrumând pacienta spre internare în clinica noastră pentru investigații suplimentare.

Elementele patologice identificate la examenul obiectiv efectuat în momentul internării au fost următoarele: asimetrie facială uşoară cu hipertrofia hemifeței drepte, mai vizibil la nivelul frunții, hipertrofia membrului superior şi inferior drepte, tegumente palide, abdomen destins, ficat la $1 \mathrm{~cm}$ sub rebordul costal drept. Hemograma efectuată în momentul internării a evidențiat anemie hipocromă microcitară (hemoglobina 11,6 g/dl, hematocrit $33,5 \%$, volum eritrocitar mediu 77,5 fL). Am efectuat teste biochimice, care au arătat nivele crescute ale transaminazelor hepatice (aspartat aminotransferaza 40,8 U/L, alanin aminotrnasferaza 33,7
U/L), fără alte modificări patologice. Serologia pentru sindromul TORCH (T-Toxoplasma, O-Altele, R-Rubeola, C-Citomegalovirus, H-Herpes) a fost, de asemenea, negativă. Ecografia abdominală a evidențiat uşoară hepatomegalie $(78,4 / 30,4 \mathrm{~mm})$, iar cea transfontanelară a arătat uşoară ventriculomegalie (diametru biventricular $38,4 \mathrm{~mm}$ ) şi discretă atrofie frontală. Datorită depistării hemihipertrofiei drepte, am ridicat suspiciunea de sindrom Beckwith-Wiedemann. Astfel, am dozat nivelul fetoproteinei, care a fost mult peste limita superioară a normalului, şi anume $30,7 \mathrm{UI} / \mathrm{ml}$ (valori normale $<6,7 \mathrm{UI} / \mathrm{nl}$ ) şi am solicitat consult genetic în vederea efectuării cariotipului din sângele periferic. Analiza citogenetică nu a evidențiat anomalii numerice sau structurale ale cromozomilor, cariotipul fiind 46, XX. Astfel, am stabilit diagnosticul de hemihipertrofie izolată, externând pacienta cu următoarele recomandări: tratament hepatoprotector timp de o lună, reevaluare clinică şi paraclinică cu ecografie abdominală peste aproximativ 3 luni.

După aproximativ 3 luni, analizele de laborator au pus în evidență un nivel uşor crescut al aspartat aminotransferazei (AST 36 U/1), fără alte modificări patologice. Dozarea alfa-fetoproteinei a evidențiat o scădere a acesteia la aproximativ jumătate din valoare iniţială, şi anume 15,9 UI/ml. Ecografia abdominală a fost fără modificări patologice. Datorită scăderii nivelului alfa-fetoproteinei şi a lipsei modificărilor patologice la ecografia abdominală, am recomandat reevaluarea pacientei peste aproximativ 6 luni.

Astfel, la vârsta de 1 an şi 4 luni, după aproximativ 6 luni de la reevaluarea anterioară, pacienta a fost internată din nou în clinica noastră în vederea repetării analizelor de laborator şi a efectuării ecografiei abdominale. Examenul clinic nu a evidențiat elemente patologice adiționale în comparație cu evaluarea anterioară. Hemograma efectuată în momentul internării a evidențiat anemie hipocromă, microcitară (hemoglobina 9,4 g/dl, hematocrit $30,3 \%$, volum eritrocitar mediu $62,7 \mathrm{fL}$, hemolobina eritrocitară medie 19,5 pg). Testele biochimice au arătat persistența nivelului uşor crescut al aspartat aminotransferazei (AST 37,3 U/L), precum şi un nivel scăzut al fierului (Fe 3,66 $\mu \mathrm{mol} / 1)$. Determinând nivelul alfa-fetoproteinei, am observat că aceasta este în continuă scădere, valoarea fiind 7,8 $\mathrm{UI} / \mathrm{ml}$, aproximativ jumătate din valoarea anterioară. Ecografia abdominală efectuată la această vârstă a fost fără modificări patologice, cu dimensiuni ale organelor în limite normale pentru vârsta actuale. Din cauza anemiei feriprive evidenţiate de analizele de laborator, am recomandat dietă bogată în 
fier (gălbenuş de ou, carne de pasăre, ficat de pasăre, fructe şi legume proaspete) şi suplimentare cu fier per oral timp de 6-8 săptămâni, cu repetarea ulterioară a hemogramei. De asemenea, în contextul patologiei de bază, am recomandat repetarea alfa-fetoproteinei şi a ecografiei abdominale peste aproximativ 6 luni.

Particularitatea cazului constă în diagnosticarea unei hemihipertrofii izolate la un sugar de 6 luni, cu test genetic negativ, la care s-a observat o uşoară asimetrie facială în momentul naşterii, cu evoluție ulterioară favorabilă, cu scădere progresivă a nivelului alfa-proteinei şi ecografie abdominală normală.

\section{DISCUȚII}

Hemihiperplazia, sau anterior numită hemihipertrofia izolată - o patologie genetică rară, cu o incidență greu de estimat în populația generală, fiind de multe ori subdiagnosticată. Literatura de specialitate raportează o prevalență a hemihipertrofiei de aproximativ 1 la 13.200 de nou-născuți vii (6), însă această estimare nu este precisă deoarece include atât cazurile izolate de hemihipertrofie, cât şi cele asociate unor diferite sindroame genetice (5). Astfel, un studiu mare, efectuat pe 860.000 de cazuri, a identificat un număr de 10 cazuri de asimetrie corporală congenitală, sugerând o prevalență de aproximativ 1 la 86.000 de nou-născuți vii (8). $\mathrm{Cu}$ toate acestea, dintre cei 10 pacienţi identificaţi cu hemihipertrofie, o parte au prezentat, de asemenea, alte trăsături sugestive pentru un sindrom genetic, cum ar fi Beckiwth-Wiedemann (8). Un alt studiu efectuat pe 14.430 de nou-născuți, într-un spital din Tokyo, a identificat un singur caz de hemihiperplazie (9). Dat fiind faptul că acestea două sunt singurele studii efectuate în literatură referitoare la acest subiect, prevalența reală a acestei patologii în populația generală este dificil de estimat (5). Cele mai multe cazuri de sindroame genetice care includ hemihipertrofia ca şi trăsătură sunt sporadice şi au risc de recurență scăzut (5). Cu toate acestea, au fost descrise cazuri de sindrom Beckwith-Wiedemann în literatura de specialitate cu agregare familială (10). Ca şi în cazul sindromului Beckwith-Wiedemann, hemipertrofia izolată apare, de asemenea, cel mai adesea sporadic, însă Heilstedt a raportat 4 membrii ai unei familii diagnosticați cu hemihipetrofie izolată (5). În cazul pacientei prezentate mai sus, nu am identificat alți membri din familie afectați de această patologie.

Cel mai mare risc în cazul pacienților diagnosticați cu hemihiperplazie izolată, cu un impact major asupra ratelor de mortalitate şi morbiditate, este acela de a dezvolta tumori pe parcursul vieții. Acest fapt se bazează pe multiplele prezentări de caz publicate în literatura de specialitate, însă şi pe studiul prospectiv efectuat de Hoyme pe 160 de copii cu hemihipertrofie izolată, care pe parcursul a 10 ani a identificat 10 tumori la 9 indivizi (11). Din cele 10 neoplazii diagnosticate, 6 au fost tumori Wilms, un hepatoblastom, 2 carcinoame de glandă suprarenală, şi un leiomiosarcom al intestinului subțire, ducând la o incidență de 5,9\% de apariţie a tumorilor (11). Într-un review pe aceeaşi temă, Lapunzina a observat că tumorile care apar în cazul pacienților cu hemihipertrofie izolată sunt asemănătoare cu cele identificate în cazul celor diagnosticaţi cu sindrom Beckwith-Wiedemann, însă nu identice (12). Astfel, deşi 94\% dintre tumori sunt intra-abdominale, la fel ca în cazul pacienţilor cu sindrom Beckwith-Wiedemann, în cazul pacienților cu hemihiperplazie izolată, pot apărea de asemenea tumori extra-abdominale care afectează creierul, testicolul, plămânul, uterul sau măduva osoasă (12). În cazul pacientei prezentate mai sus, nu am identificat până la vârsta actuală nici un tip de tumoră.

Există, de asemenea, alte patologii non-neoplazice, care pot apărea în cazul pacienților cu hemihipertrofie izolată, precum: sindromul de tunel carpian (13), hemihipertricoză (14), hiperplazie nodulară focală a ficatului (15), obstrucția căilor aeriene superioare (16), hipoacuzie sau surditate (16), boala Lenarduzzi-Cachi-Richi sau rinichiul „spongios“ (17). Nu am identificat nici una dintre aceste asocieri în cazul pacientei noastre. Cu toate că obstrucția căilor aeriene asociată cu hipoacuzie sau surditate este descrisă în cazul pacienților cu hemihipertrofie facială, pacienta noastră deşi s-a prezentat cu hipertrofia feței drepte nu a dezvoltat până în prezent nici una dintre aceste două complicații.

\section{CONCLUZII}

Hemihipertrofia izolată trebuie suspicionată în cazul identificării unei hipertrofii a unui hemicorp sau a unei zone din corp, cum ar fi fața, abdomenul sau membrele. Consultul genetic este obligatoriu în vederea excluderii sindroamelor genetice care pot asocia în tabloul clinic hemihipertrofia. Pacienții diagnosticați cu hemihiperplazie izolată trebuie să fie supuşi periodic unei ecografii abdominale, precum şi dozării alfa-fetoproteinei în vederea depistării precoce a unui posibil proces tumoral. 